\title{
Waldegrave defends 'foresight' exercise
}

London. William Waldegrave, Britain's science minister, has refuted claims that moves by the Office of Science and Technology (OST) to devise a strategy for choosing research priorities through a programme of "technological foresight" are running into difficulties.

But the OST seems to have implicitly accepted some of the criticisms of the programme that have been made in recent weeks. Speaking at a meeting at the Royal Society in London on Monday evening, for example, Waldegrave emphasized the need for research priorities to be determined by market needs, not merely by the "technology push' that many feel characterized some early drafts of the programme produced by the OST

$\mathrm{He}$ also acknowledged that pressures to achieve short-term results for the programme could undermine its long-term effectiveness. Waldegrave said that the truth was "somewhere in between" those who wanted quick action, and others who argued that the OST was already moving too fast.

The technology foresight programme is central to government's efforts to restructure its support for science and technology, as outlined in the recent white paper (policy document) Realising our Potential. In particular, it is being seen as the main device for imposing industrial priorities on the science base, for example by making research councils aware of those fields of science most likely to obtain government support.

A special committee, chaired by Bill Stewart, the government's chief scientific adviser, has been set up to oversee the programme. And two outside consultants, the consulting firm Segal Quince Wicksteed of Cambridge and the Programme of Policy Research in Engineering Science and Technology (PREST) at the University of Manchester have been appointed to organize

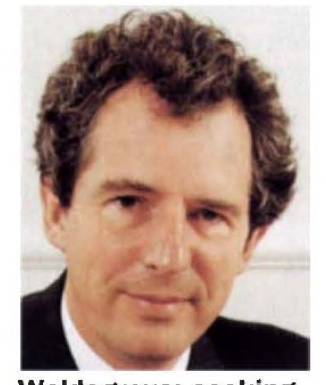

Waldegrave: seeking a new partnership. detailed surveys of expert opinion using the Delphi techniques pioneered in both the US and Japan.

In an attempt to draw attention to the exercise - and also to drum up support for it from a somewhat sceptical research and industrial community - a series of seminars are being organized throughout the country.

Some of the initial scepticism has been dispelled by the seminars, particularly those which have included presentations from industrial research managers emphasizing the value of forecasting techniques in their own companies. A meeting at the Confederation of British Industry last week, for example, heard precisely such a pitch from John Taylor, research director for Hewlett Packard.

But the meetings have also provided a platform for expressions of concern over the way that the programme is being run so far. One is a perceived danger that it may be taken over by the Whitehall civil servants. Evidence of this, it has been claimed, is the way that the OST produced a list of suggested technological priority areas, even before the consultation process had properly begun.

There are also widespread fears that the OST, under strong pressure from the Treasury to impose priorities on the science budget, may be trying to run before it can walk. "Why not concentrate on one or two areas first, and make sure you get those right", says one critic.

OST officials say they are well aware of each of these dangers, and are taking steps to minimize them. On the question of communication, for example, Waldegrave says a key function of the seminars - and indeed of the whole programme - is to help build a partnership between industry, academia and government.

OST's response has gone some way to placating its critics. "The whole project seemed to be in something of a mess a few weeks ago, but since then things have been picking up a bit", says Sir Mark Richmond, chairman of the Science and Engineering Research Council. But a high degree of scepticism remains.

Fiona Steele, of the Confederation of British Industry's(CBI) innovation unit, acknowledges that the OST is now listening to the CBI's concerns. But she says that there is still a long way to go before the confederation is satisfied that the programme is on track. "The proof of the pudding will be in the eating", says Steele. David Dickson

\section{South African cyclotron faces uncertain future}

Cape Town. South Africa last week became only the fifth country in the world - - after Sweden, Japan, Russia and the United States - to offer high-energy proton therapy to cancer patients when the first such treatment was given to a patient at the country's National Accelerator Centre (NAC).

But controversy continues to dog the centre as questions are raised about the high proportion of the national research budget being absorbed by a facility now being used primarily for medical purposes. And the new government, which is due to be elected in April and which is likely to reassess research priorities, could well decide to withdraw its support.

Roger Jardine, who holds the science and technology portfolio in the African National Congress's Department of Economic Planning, says that the organization is not keen to support "big science" through projects intended to "glorify the state" as the National Party government has in the past.

The NAC is administered by the coun- try's main science funding agency, the Foundation for Research Development (FRD). Its running costs are R34 million (US\$10 million) a year, a figure that represents just under 30 per cent of the foundation's operating budget.

In the past, this level of expenditure has been justified by foundation officials on the grounds that funding for the accelerator centre is earmarked by the cabinet, and could not be unilaterally reallocated to other scientific priorities.

The major facility at NAC is a variable energy cyclotron capable of producing 200$\mathrm{MeV}$ protons (see Nature 327, 271; 1987). Since the cyclotron became operational six years ago, the proportion of beam time used for nuclear physics has fallen to 35 per cent, partly because the energy range at which it operates is of relatively low scientific interest; the rest of the time is used for neutron therapy, radiobiology research and the production of short-lived diagnostic isotopes.

Treatment at NAC is provided free of charge. But the number of patients who have received neutron therapy at the centre, for salivary gland and advanced breast tumours, is small, averaging about a hundred a year for the past five years.

Proton therapy is prescribed for tumours close to the spinal cord or optic nerve, and those in or near the brain, as it does not affect surrounding healthy tissue. Its advent should increase the number of patients treated by the centre. NAC receives only a small private income from the sale of isotopes: $\mathrm{R} 670,000$ last year.

If the facility fails to win the support of the new government, one option would be privatization. This could require a controversial shake-up among its personnel. The centre's director, Daan Reitman, revealed last week that well over half of its annual budget is needed for staffing costs. With a total of 200 employees, the average cost per employee is R100,000, an extremely high figure by South African standards.

Michael Cherry 